\title{
Political Sources of Hungarian Soft Power ${ }^{1}$
}

\author{
PÉTER KACZIBA
}

\section{sciendo}

Politics in Central Europe (ISSN: 1801-3422)

Vol. 16, No. 15

DOI: 10.2478/pce-2020-0005

\begin{abstract}
In the past decade, Joseph Nye's concept of soft power has become a popular tool for analysing and explaining foreign policy directions of countries that lack significant capacities of hard power. Beyond other states, Hungary has also received special attention in this regard as several surveys and indexes have measured a high increase in its soft power efficiency. This paper attempts to analyse how Hungarian domestic and external political approaches supported this assumed progress and seeks to understand how political values, governance practices and foreign policy strategies have influenced the effectiveness of Hungarian soft power. The paper will argue that the recent Hungarian political directions have produced controversial outcomes and the populist orientation has increased and, at the same time, constrained the effectiveness of soft power. It has increased because populist rhetoric has created a much larger international fame and agenda-setting capacity than would have been expected from a small Central European country. However, it has also been constrained because controversial domestic and conflicting foreign policies were rejected by the European moderate majority. As a result, today, Hungarian external policies suffer from a serious deficit of legitimacy and moral authority which significantly limit the presumed progress of soft power.
\end{abstract}

Keywords: soft power, Hungarian politics, political values, governance, foreign policy

1 Supported by EFOP-3.6.3-VEKOP-16-2017-00007 - Young researchers from talented students - Fostering scientific careers in higher education. 


\section{Introduction}

In recent years, objective international surveys began to claim that Hungary managed to increase its soft power capabilities. According to Portland Communication's survey, Soft Power 30 , Hungary had the $25^{\text {th }}$ most effective soft power in 2018, thus preceding more influential countries such as China $\left(27^{\text {th }}\right)$, Russia $\left(28^{\text {th }}\right)$ or Brazil $\left(29^{\text {th }}\right)$ (McClory 2018: 43). According to the survey, Hungary has managed to improve three positions since 2017 which means a surprisingly rapid change since 2015 , when the country did not even make it into the Top 30. Elcano - which measures global visibility concerning military, economic and soft components - has come to a similar conclusion. In this survey, Hungary ranked $33^{\text {rd }}$ out of the 110 countries on the soft presence chart of 2017. Elcano's results indicate the increasing effectiveness of Hungarian soft power: in 2016, only $37.3 \%$ of Hungary's soft power sources contributed to the country's international visibility, whereas this rate was as high as $41.2 \%$ the following year (Olivié - Garcia 2018).

Without accepting the results of these surveys, it can be stated that Hungary's international visibility has truly increased in recent years. As a result of its new Global Opening foreign policy doctrine, Hungary today endeavors to achieve more frequent cooperation with the outskirts of Europe, Asia and some African countries. Hungarian foreign policy is becoming more active - and sometimes more confrontational - in the neighbouring countries as well, whose tendency is related to the current government's more extensive diaspora policy. Viktor Orbán Prime Minister's governments have also established Hungarian cultural posts and institutions abroad, while the Stipendium Hungaricum Scholarship Programme provides opportunities for thousands of students from abroad to study in Hungary. The Hungarian leadership is also active in exploiting the opportunities provided by the printed and online press; state television broadcasts daily news reports in English, German, Russian and Chinese, while government-related media enterprises are expanding their ties towards neighbouring countries and the Balkans. Besides these direct and government-controlled measures, Hungary enjoys the controversial advantages of indirect international media attention. Although these press reports often criticise the FIDESZ (Alliance of Young Democrats) government, on the other hand, they also provide continuous international attention for Viktor Orbán's arguments and advertise his political strategies (Glied - Pap 2016).

The direct and indirect international effects of the Hungarian leadership's political decisions have not only stimulated international interest towards FIDESZ's arguments but also increased the popularity of Viktor Orbán's political agenda - mainly among the European nationalist and/or Eurosceptic voters and parties. Nowadays, actors of the European radical right-wing consider the Hungarian PM an idol; Orbán has a notably large number of followers on online 
platforms (e.g. Figure 1, 2), while Politico's Power Matrix survey named him one of the most influential leaders in Europe (Heath 2016). This increasing fame and the political discourse created by it keep Orbán's agendas in focus and contribute to the seemingly apparent strengthening of Hungary's soft power.

\section{Figure 1: Pageviews of selected EU politicians' Wikipedia sites (7/1/2015-1/4/2019)}

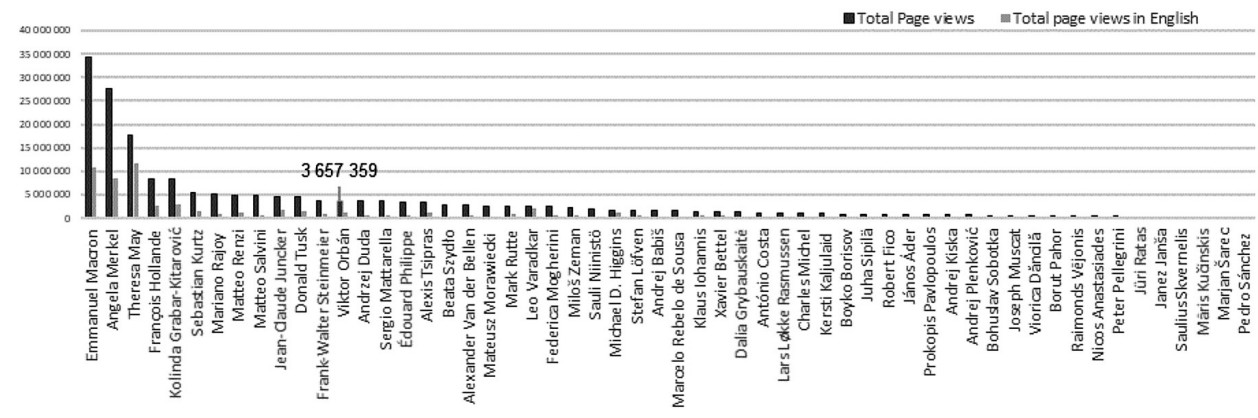

Source: author according to www.wikipedia.com, Pageviews Analysis. Data collected on 4 January 2019.

Figure 2: Facebook page likes of selected EU politicians (1/5/2019)

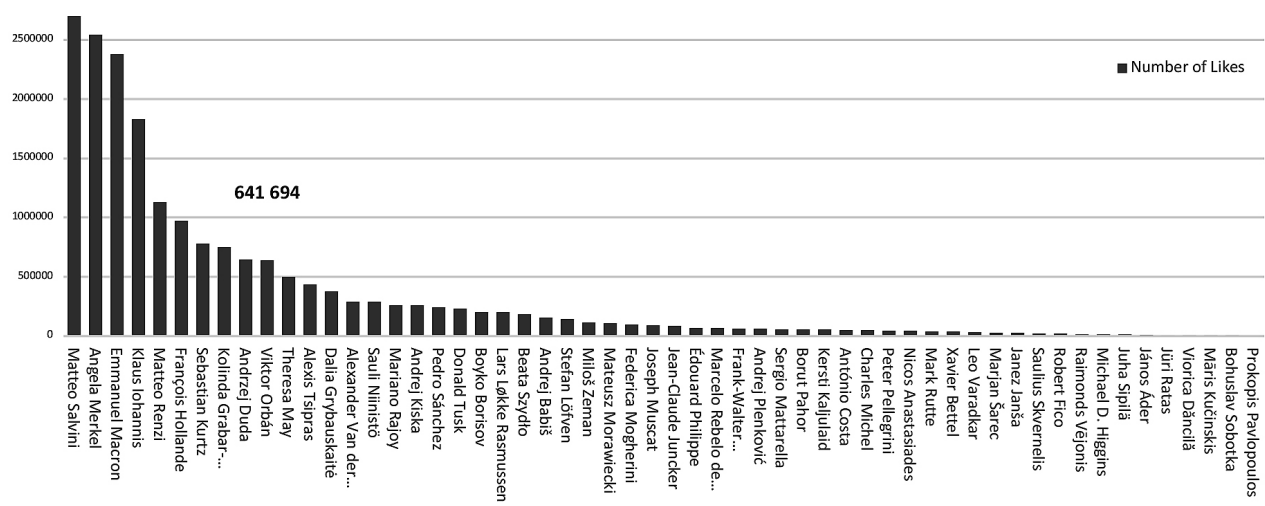

Source: author according to www.facebook.com. Data collected on 5 January 2019.

The surveys quoted above examined the effectiveness of soft power by evaluating the efficiency and attraction of various factors such as politics, culture, education, sports and digital development. Without underestimating the significance of other components, we can draw the conclusion that in the case of Hungary, the political sphere was among the most important sources of soft power, influencing - intentionally or not - the international effects of Hungarian foreign policy. In other words: due to the limited sources of hard power, political capability 
has become one of the most important means of Hungarian foreign policy. The political capabilities of Hungarian soft power were based on domestic practices: the political, economic and communication techniques which were used domestically during the extensive centralisation processes have also become the sources of a Hungarian soft power agenda that evidently used domestic examples to gain further popularity in the international arena, especially among those who already sympathised with the Orbán government's unorthodox approaches.

This paper attempts to examine which political factors could have been exploited by soft power means and how politics affected those perceptions that have shaped international opinion on contemporary Hungary. The study has identified three widely interpreted political spheres during the detection of the most effective segments of soft power tools: the political values, the efficiency of domestic governance and the attraction of foreign policy actions. These political segments were determined through bibliographical research, thus the evaluation of Hungarian soft power's political sources will be outlined by existing theoretical frameworks. In the case of political values, I review and examine the attractiveness of the Hungarian government's ideological explanations. In the context of governance, I outline the most important frameworks of governing strategies and analyse the international reputation of Hungarian domestic methods and nationally achieved results. In relation to foreign policy, I identify tools that enhanced the effectiveness of Hungarian soft power, while also pointing out the limitations of the conflicting foreign policy framework.

\section{Theoretical background}

Joseph Nye's original concept of soft power is based on the assumption that power itself has inherent abilities to force our own will on others. Sources of these abilities may be coercion, compensation or co-optive behavior (attraction); the latter perhaps working through the popularisation and credibility of goals which - even without persuasion - can make others accept these aims as their own preferences. According to Nye's theory, every mechanism in foreign policy that achieves its goals by force or compensation is related to hard power abilities, while those based on attraction are more related to soft power capabilities (Nye 2008: 94-95).

According to Nye, soft power is the states' ability to achieve their goals through attraction, rather than through force or compensation. While in the case of hard power, military threat or economic capacity may serve as convincing forces, the sources of soft power are based on factors such as political strategy, culture or ideology which - in the case of effective usage - may influence public opinion of foreign countries. Soft power is effective if the state applying it becomes credible for the majority of international actors and if the desired political, cultural, ideological or other strategic goals become acceptable examples for others (Nye 1990: 166-171; 2004: 2-32). 
In his reviewed analysis published in 2004, Nye divides three sources of effective soft power: culture, political values and foreign policy. According to his explanation, soft power becomes an effective tool if the culture of a country is attractive for others; if projected political values show positivity at home and popularity abroad; and if foreign policy creates international legitimacy and moral authority (Nye 2004: 11). In this sense, culture can be interpreted broadly, ranging from academic ideas to Hollywood or Bollywood films. However, the external effects of domestic culture always depend on context, as Nye puts it: "Coke and Big Mac do not necessarily attract people in the Islamic world to love the United States" (Nye 2004: 12).

This is the feature which connects the cultural and political segments of soft power. Culture's attraction abilities are greatly influenced by the political values and foreign policies that the concerned countries represent. In relation to this, Nye highlights that government policies strengthen strategies related to soft power if their most important ideas are based on real national interests and opinions of the wider public and if the government's credibility can be maintained by honest and straightforward interactions (Ibid 14). Thus, the effectiveness and credibility of domestic politics also affect the efficiency of foreign politics, but domestic trustworthiness and popularity can only be exported if the government is able to display a positive self-image in the international arena (Ibid 12).

\section{Table 1: Sources and metrics of soft power}

\begin{tabular}{|c|c|c|c|}
\hline \multirow{2}{*}{ Joseph Nye } & Soft Power Survey & Global Presence Report & Soft Power 30 \\
\cline { 2 - 4 } & (Monocle) & (Elcano) & (Portland) \\
\cline { 4 - 4 } & Culture & Development cooperation & Digital (objective) \\
\hline Culture & Diplomacy & Education & Culture (objective) \\
\hline Foreign policy & Education & Science & Enterprise (objective) \\
\hline & Business/Innovation & Technology & Education (objective) \\
\hline & Government & Information & Engagement (objective) \\
\hline & & Culture & Government (objective) \\
\hline & & Sports & Global culture (subjective) \\
\hline & & Tourism & Luxury Goods (subjective) \\
\hline & & Migration & Technology Products (subjective) \\
\hline & & & Cuisine (subjective) \\
\hline & & & Livability (subjective) \\
\hline & & & Friendliness (subjective) \\
\hline & & & Foreign Policy (subjective) \\
\hline
\end{tabular}

Source: Nye 2004: 12; McClory 2010: 9-13; Olivié - Garcia 2018: 40; McClory 2018: 169-171. 
As Nye's approach only makes an apparently wide categorisation possible, surveys that rank and index soft power aim to create more accurate classifications. For instance, a Soft Power Survey, concluded by Monocle magazine (Table 1.) - beyond culture and politics - also focuses on education, business and innovation (McClory 2010: 9-13). Besides these, Elcano's Global Visibility Index, as mentioned earlier, also places emphasis on science, sports, technology, information, tourism and views on migration (Olivié - Garcia 2018: 40). The most complex approach is given by Soft Power 30, concluded by Portland Communications, which differentiates objective and subjective components when measuring soft power effectiveness. Concerning objective components, digital infrastructure and engagement are novelties compared to the other surveys mentioned above. The subjective components are based on a poll with samples of 500 respondents and they include attitudes towards each country from the popularity of national cuisine, through the friendliness of citizens to the attraction of foreign policy (McClory 2018: 169-171).

Without claiming exclusiveness of any opinion or classification, we can state that the political sphere itself is named at least in three of the aforementioned approaches. When defining the sources of soft power, Nye identifies political values and foreign policy; Monocle encounters government and diplomacy; while Portland Communications measures the role of the political sphere in soft power through the categories of government and foreign policy. Political factors, therefore, have emphasised significance in both the theoretical and practical approaches: the theoretical definitions and the measuring indexes both acknowledge the role of politics in the efficiency of soft power. This observation is not surprising as it is obvious that decisions related to soft power or hard power are both parts of the broadly interpreted politics and policy-making process.

Nevertheless, this study does not examine the role or process of policy-making, rather, it attempts to highlight those Hungarian political factors that may seem attractive or repulsive abroad. To achieve this goal, I shall use political-related soft power metrics of the literature listed in Table 1. From these metrics, political values, foreign policy, government, diplomacy and (international) engagement are the factors that should be distinguished when defining politics-related segments of soft power. Though the role of policy-making is also present in other categories, the latter ones were highlighted because these factors take part directly in a country's political attractiveness or repulsiveness. A state's political values, foreign policy, government, diplomacy and engagement directly influence the political segments of a certain state's soft power, while culture, sports, technology (etc.) attached to the political sphere only do so in an indirect way. (For instance, Russia's foreign policy directly shapes the country's political image abroad, while Russian achievements in sport only indirectly affect the attractiveness of certain Russian policy-making related to sport.) 


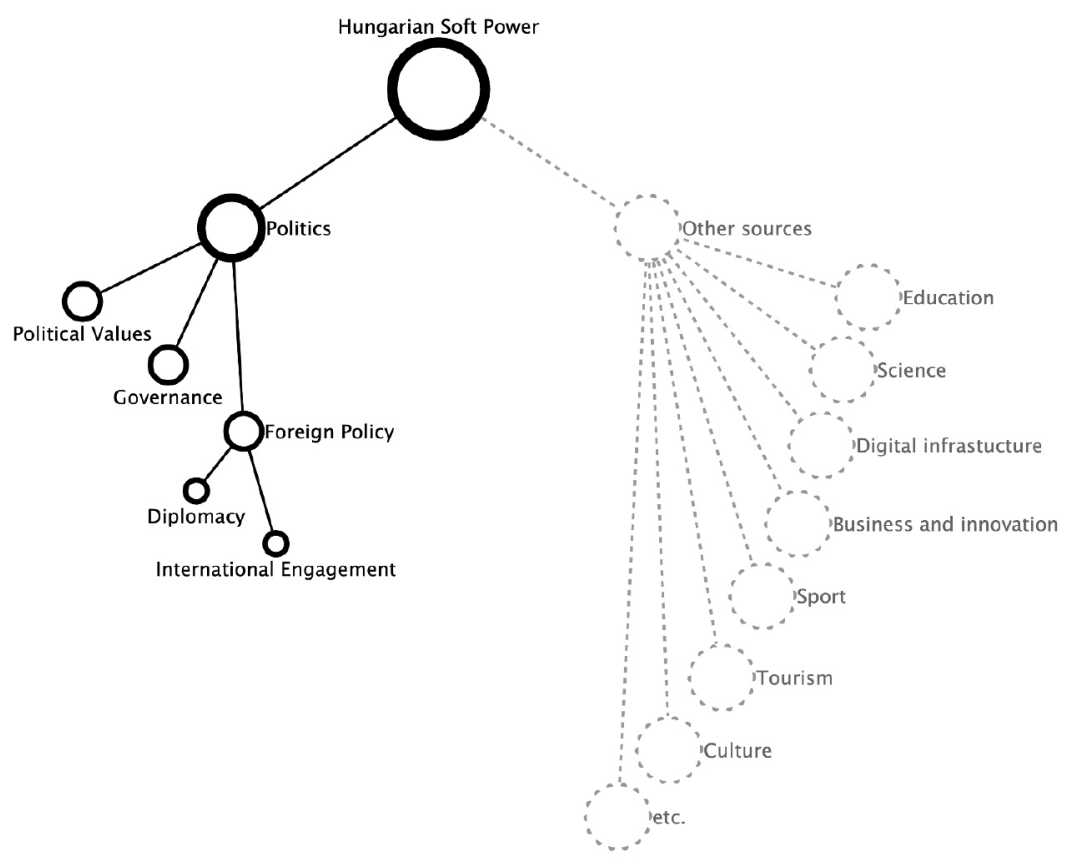

Source: author

As these political sources of soft power were determined through the comparison of different bibliographies, it is important to filter identical items and create groups of units of analysis. This aspect of the study is summarised in Figure 3. In this schematic draft, the broadly interpreted political sphere is part of the soft power sources just as culture, education, business or tourism. Within the political sphere - taking literature reviews into account - I differentiate a segment based on political values, one on governance and another one on foreign policy, the latter of which includes diplomacy and (international) engagement as well. These units outline the analytical framework of following chapters while also marking the most critical hardship of the methodology, namely: political factors of soft power significantly affect each other and are therefore quite difficult to be examined separately. Thus, it is important to highlight that our analysed units - political values, governance and foreign policy - are not separate segments of the political sources of soft power, rather, elements that reciprocally shape and affect the projected political image of Hungary. 


\section{Political values}

Political values are closely connected to the most basic values of human societies and - in ideal cases - are recorded in the fundamental values and rights of constitutions and laws. Politics play a crucial role in the definition of morally and legally accepted values. Political decisions show preferences towards values we find positive, while rejecting those we find negative (Bihari 2013). A unique characteristic of positive values is that their positivity is relative. Positive acceptance of values depends on context, interpreter, recipient and on the question of what we consider to be positive or negative. In extreme cases, this relativity characteristic can even be true for the most fundamental values: the positivity of peace may be questioned in war propaganda, the equality of individuals can be doubted in group conflicts, extreme power centralisation may become rational in cases of assumed or real external threats, while environmental pollution may also be legitimised by economic interests. Political socialisation and individual experience are essential parts of the formation of political value preferences, while political choices might also be influenced by innovative political marketing that exploits the failures of previous political practices (Ethridge - Handelman 2010: 69). The failure of practices might undermine the positivity of related values or may transform formerly accepted norms - blamed to be part of the dismissed political model - into negative aspects.

The relativity of political values' positivity or negativity will define the content of the following pages: I will assume that judgments over Hungarian policy-making are characterised by relativity and, thus, depend on context, interpreter, recipient and on the question of what we consider to be positive or negative. For instance, political values and practices represented by the Hungarian government are often criticised by mainstream Western European politics and academics, however, they are increasingly supported by those who are dissatisfied by this mainstream or the values they represent. The dichotomy of rejection and support underlines the fact that there is no unified judgment over politics: values, projected ideas or policies might be considered differently and according to various interests (Geuss 2009: 32-33). This feature of relativity obviously creates opportunities for those who propose less popular policies, however, it also indicates that, in the diverse environment of opinions, still the most popular policies may produce the greatest effects. Thus, in terms of soft power's efficiency, relativity might serve as an opportunity and, at the same time, as a major constraint. An opportunity because, as a result of relativity, even less coherent political opinions might find and impact their audience; and a constraint because, in the end, popularity and the number of supporters will define soft power's effectiveness. As we will see later, Hungarian soft power benefits and suffers from these characteristics: the Orbán government has deliberately exploited the growing dissatisfaction of domestic voters and has created a for- 
eign policy that utilises the eroding popularity of liberal democracy. However, it also suffers from the rejection of the European majority who cannot accept principles of illiberal democracy and considers it an extremist idea supported only by a radical minority. These controversial characteristics shape Hungarian soft power approaches which purposefully target the traditions of liberal democracy and attempt to gain support by undermining the values of this seemingly declining political era. This, however, does not mean that Hungarian soft power attempts the impossible and tries to change the values and principles of major international actors. Rather, it means that the current Hungarian government seeks to exploit existing international trends and tries to offer an unorthodox approach to those who already embrace radical policies.

The FIDESZ after coming to power again in 2010, sensibly developed its domestic political strategy based on these assumed trends and developed political values which were domestically popular, supported centralising efforts and helped to maintain government position. The strategy intentionally attempted to distance itself from the gradually discredited political approaches of previous governments and determined itself as the creator of a new domestic order, the initiator of a new Hungarian regime change. The leader of this process, Viktor Orbán, behaved as a reconstructive regime founder leader whose aim has been to demolish the former system and establish a new one (Illés - Körösényi - Metz 2017: 116). According to the new rhetoric developed by Orbán, after the seemingly irrefutable reign of "liberal post-communism", the newly formed system, the System of National Cooperation (Nemzeti Együttmüködés Rendszere - NER) was going to lead to the establishment of a pragmatic governance that replaced the former era with a new social contract (NER 2010; G. Fodor - Fürész - Giró-Szász 2010). The pillars of this new contract were work, home, family, health and order, while the exact government programs were characterised by centralised governance, the protection of national sovereignty, statist economic policy, the support of the middle class, focus on historical traditions and the representation of Christian values (Rajcsányi 2018: 130).

New values defined by the NER were based on a wide range of political and economic considerations. In short, political considerations can be characterised by FIDESZ's requirement of vote maximisation and a need to maintain a governing position. To fulfill these primary aims, the Orbán governments have developed effective methods to influence the political views of the public and, at the same time, assimilated and monopolised historical and contemporary preferences of the Hungarian majority. A value survey, conducted by TÁRKI one year before the FIDESZ's two-third victory in the 2010 elections, perfectly reflects these societal preferences (Tóth 2009: 13). According to the survey, Hungarian society is characterised by a lack of trust, a sensation of injustice, paternalism and apparent disorder in norms. TÁRKI has also found that the majority of Hungarians consider civil and political rights to be less important, 
the trust in institutions is weak and there is a low tolerance towards diversity or atypicality (Ibid).

These features have accurately reflected the historical characteristics of Hungarian society and shown the continued existence of preferences developed during the socialist decades of Kádár's 'Goulash communism', in which the majority sacrificed the opportunity to practise individual and social-political liberties in exchange for the slow but gradual improvement of living standards (Bretter 2014: 152). These historical preferences were not just rediscovered by FIDESZ but were further utilised to promote values that helped the legitimisation of government efforts such as over-centralisation, the creation of a new national economic elite or policies of antimigration. This unilateral value-promoting policy effectively eroded formerly accepted positive principles and, in return for (slow) progress and (assumed) protection of sovereignty, supported the legitimisation of expanding government control over almost all aspects of politics and economy.

Besides politics, the value system promoted by the Orbán governments was also influenced by the ideological approaches of the so-called "economic struggle for freedom". The economy-based values exploited the societal grievances of the 2008 financial crisis which caused severe recession in Hungary and especially negatively affected the middle-class. FIDESZ, which exploited the consequences of the crisis and managed to achieve a two-thirds electoral victory in 2010, promoted values that rejected causes and effects of the financial crisis: the creation of financial independence, the taxing of multinational corporations, the establishment of a national bourgeoisie, the financial empowerment of the middle class were all popular slogans that any voter who was disappointed by the liberal market economy could agree with. According to the new rhetoric, the restoration of the economy has become a freedom fight based on interpretations related to historical dramas and traumas. This struggle was fought against foreign banks, creditors, billionaires and the domestic or foreign representatives of the global financial system (i.e. George Soros, IMF, EU etc.). Gaining back national sovereignty (by extending state engagement and ownership), punishing multinational enterprises (by, for instance, taxing banks), or the selective interpretation of economic competition (during the establishment of a national capitalist class) have all become positive values in the rhetoric of this freedom fight.

Though we will deal with governance in the following section, it is worth highlighting here that the value systems created after 2010 were also influenced by the introduction of controversial governing practices. These practices reflected the theoretical views of the Hungarian right-wing which intentionally attempted to distance itself from the neoliberal good governance model that supported extended pluralism and presumed a self-controlling society. Instead, FIDESZ believed in the effectiveness of a good government model in which the 
active, intelligent and strong state is the main force in preserving the balance between market and society, applying problem-based decision-making and representing the majority's interests effectively (Stumpf 2009: 111-112; Böcskei 2013: 2). Values related to this governance model were publicly reviewed in the infamous speech of Tusnádfürdő (Băile Tușnad), in 2014, when Viktor Orbán claimed that, "...the new state that we are constructing in Hungary is an illiberal state, a non-liberal state. It does not reject the fundamental principles of liberalism such as freedom, and I could list a few more, but it does not make this ideology the central element of state organisation; instead, it includes a different, special, national approach" (Kormány.hu 2014).

To sum up, Orbán governments during their reign since 2010 have developed new domestic political values influenced by political, economic and governance considerations. These values operate with phrases like: strong centralised government, the protection of national sovereignty, statist economic policy, support of the middle class, consideration of historical traditions and the representation of Christian values (Rajcsányi 2018: 130). During the social embedding of these values, FIDESZ intentionally degraded positive values represented by the previous governments and declared itself the only assurance for the survival of the Hungarian nation. FIDESZ's electoral successes after 2010 demonstrate perfectly that the legitimisation of the new value system succeeded, as the majority of Hungarian society could partly or wholly adapt the new principles.

The domestic acceptance of these principles is a key factor in understanding the international attraction of Hungarian political values. Although these values were developed for a domestic audience, they reacted to problems that are commonly present abroad as well. The stagnation or decline of the middle classes, the presence of inequalities, unemployment, unaffordable real estate prices, the difficulties of small- or medium-sized businesses and social changes related to migration are all examples of challenges that cause tension outside Hungary as well (Glied - Keserü 2016: 263). Although individual countries and societies give different answers to these challenges, it is still a general tendency that populist parties, who provide easy answers to these difficult questions, are becoming more attractive, while positive attitudes towards more liberal values are decreasing along with the popularity of moderate politicians. Many scholars already pointed out these tendencies during the Cold War (e.g.: Habermas 1975; Huntington 1975), while today, a series of empirical research attempts to understand declining attitudes towards democracy. For instance, Freedom House's survey from 2018 shows that political rights and the opportunity to practise civil rights of liberty have decreased in the past 12 years and liberalism's post-Cold War expansion has practically halted (Abramowitz 2018:1). Pew Researches' surveys also report the recession of democracy: though in the economically advanced and politically more stable Western countries, democracy is still one of the most supported alternatives, at least a quarter of the respondents 
would not object to the rule of a strong leader. It is also indicative that $17 \%$ and $30 \%$ of the sample claimed representative and direct democracy to be negative, $24 \%$ found military governance acceptable, while 52\% was dissatisfied with the current framework of democracy in general (Wike - Fetterolf 2018). As it is revealed from the data of Table 2, the acceptance of non-democratic political structures is particularly high in Central and Eastern Europe (hereinafter referred to as CEE). In this region, at least 10 countries were measured to have a higher acceptance towards nondemocratic governance than in Hungary.

Table 2: Percentage who believe that...

\begin{tabular}{|c|c|c|c|}
\hline & $\begin{array}{c}\text { Democracy is preferable } \\
\text { to any other kind of } \\
\text { government. }\end{array}$ & $\begin{array}{c}\text { In some circumstances, a } \\
\text { nondemocratic government } \\
\text { can be preferable. }\end{array}$ & $\begin{array}{c}\text { For some like me, it doesn't } \\
\text { matter what kind of } \\
\text { government we have. }\end{array}$ \\
\hline Greece & 77 & 15 & 6 \\
\hline Lithuania & 64 & 15 & 17 \\
\hline Croatia & 54 & 19 & 21 \\
\hline Armenia & 53 & 13 & 32 \\
\hline Romania & 52 & 28 & 17 \\
\hline Czech R. & 49 & 27 & 18 \\
\hline Hungary & 48 & 26 & 22 \\
\hline Poland & 47 & 26 & 20 \\
\hline Bosnia & 46 & 22 & 23 \\
\hline Estonia & 46 & 29 & 17 \\
\hline Bulgaria & 39 & 34 & 23 \\
\hline Belarus & 38 & 35 & 26 \\
\hline Ukraine & 36 & 31 & 19 \\
\hline Latvia & 34 & 30 & 28 \\
\hline Russia & 26 & 41 & 26 \\
\hline Moldova & 31 & 28 & 26 \\
\hline Serbia & 36 & $2017 / 05 / 10 / d e m$ \\
\hline
\end{tabular}

Source: Pew Research Center: http://www.pewforum.org/2017/05/10/democracy-nationalism-and-pluralism. Survey conducted in June 2015-July 2016.

In parallel to the degradation of values related to democratic structures, the popularity of populist parties is constantly increasing. According to the Guardian's estimation, one in every four European citizens voted for a populist party in 2018, while the European population living under the rule of populist govern- 
ments increased from 12.5 million in 1998 to 170.2 million by 2018 (Lewis et al. 2018). The increasing popularity of populist and radical parties naturally causes the expansion of their represented values. These attitude changes are also excellently demonstrated by Eurobarometer's survey that was meant to measure opinions related to the most significant challenges of the European Union. It is highly enlightening to compare all of the results of 2013 and 2018 (Figure 4) but one of the most important conclusions is that fears related to migration and terrorism take the lead by 2018. Consequently, in 2018, the majority of Europeans were concerned about issues that were at the forefront of the Hungarian government's domestic and foreign politics.

\section{Figure 4: What do you think are the two most important issues facing the EU at moment?}

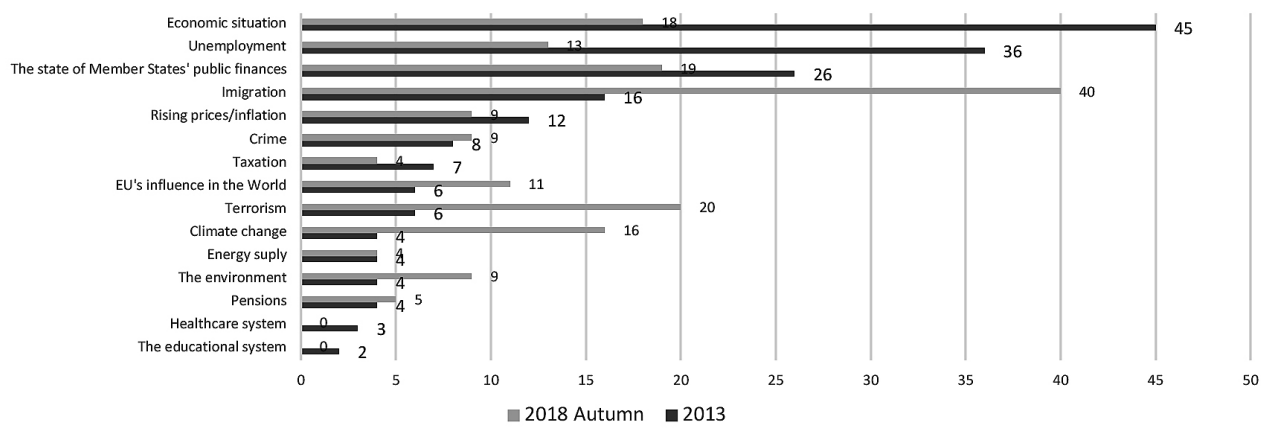

Source: Standard Eurobarometer, 2013; 2018: http://ec.europa.eu/commfrontoffice/publicopinion/index. $\mathrm{cfm} /$ General/index.

After this short review on the trends of democracy and populism, it is obvious that the Hungarian government was able to find its own audience and popularise its political values. One of the most decisive pillars of Hungarian soft power was that Viktor Orbán's populist approach offered a wide variety of potential identification. The values represented by him reflected the preferences of a significant minority of the European voters: the protection of national sovereignty, the empowerment of historical and Christian traditions, the denial of multiculturalism, the 'punishment' of multinational corporations and the rejection of the ineffective liberal elite were all popular phrases even in Western countries. Consequently, unorthodox values and policies have found their external audience, while the political factors of Hungarian soft power have attracted many layers, from Matteo Salvini through Nigel Farage to the average Facebook follower of Viktor Orbán. In this group, Orbán was often considered a political role model, a strong leader figure who stood up against the traditional European elites. 
At this point, the most important question is how large and significant the group is that embraces Orbánian values? This question will be analysed in the following section; first, however, the international attraction of Hungarian governing methods should also be examined.

\section{Governance}

While a government's political values influence the country's international reputation by establishing abstract ideological explanations, in the case of governance, the image of a certain leadership and its governing methods may become attractive or repulsive. According to Nye, government policies strengthen soft power if they manage to maintain the government's credibility both inland and abroad through honest and straightforward interactions (Nye 2004: 14). Credibility based on domestic achievements might be exported to the international environment: a government and the methods applied by it may become attractive in the international sphere if the domestic positive image is acceptable and adaptable abroad. From Canada through Sweden to Switzerland, numerous states have attempted to apply tactics that create positive self-image abroad. As we will see later, Hungary's foreign policy shows a more diverse picture in this context. While the examples above, Canada, Sweden and Switzerland wish to create an overall positive picture, Hungary intentionally takes a conflicting approach in its foreign policy. Narratives employed by the Hungarian government are not meant to convince critics, rather, they are intended to show another alternative to those who are dissatisfied with mainstream political approaches (Vörös 2018). Before we study the details of this controversial image, it is worth examining the domestic governance methods created by the Hungarian leadership. These governance methods serve as a basis for the political sources of Hungarian soft power, represent domestically tested practices and are being used to promote and prove FIDESZ's controversial views abroad.

As I pointed out earlier, FIDESZ favors the good government paradigm over the neoliberal good governance model (Böcskei 2013: 2; Stumpf 2009: 111-112). While practices of good governance aim to decrease participation of the state and increase the role of the 'invisible hand', the good government model aims to 'regain' governance. It favors the assistance of an active, strong and intelligent government which, in the name of all-inclusive solidarity, protects public interests from the harmful effects of free market mechanisms (G. Fodor - Stumpf 2007: 93). Consequently, in this model, the state is the most important actor of democratic problem-solving: its active intervention does not only secure the effective and reasonable utilisation of resources but also ensures that everyone can participate in discussions dealing with public affairs (G. Fodor 2008: 133-134). Good government completes democracy in this sense; the active state in the model defends citizens from the repulsive effects of unorganised 
freedom, protects exploited layers of society and provides guidance for the most competitive economic sectors.

At least theoretically. In practice, however, the good government model, as with the good governance paradigm, suffers from many weaknesses. The first among these is definitely connected to the idea of representation: it is quite impossible to represent the interests of everyone and even in the best-case scenarios, 'all-inclusive solidarity' may include only the majority. The model also assumes impartiality and neutrality of the state which is too idealistic assumption and ignores the fact that even the most democratic governments need to win elections and thus have their own set of interests. The model also disregards the positive effects of decentralisation while it assumes that all governments are intelligent enough to calculate best-case scenarios.

These controversies overshadowed the ruling periods of the Orbán cabinets as well. Although FIDESZ was able to develop a centralised political, socioeconomic and cultural basis for introducing components of the good government paradigm, the established strong and active state was far from being neutral and impartial: it intentionally excluded those who had different opinions and designed governance techniques which helped to maintain power but neglected major elements of the public challenges (e.g. corruption, healthcare, education, housing, etc.). The extensive reform processes following the election of 2010 were determined by strategies for consolidating and maintaining power and, according to Böcskei, they were directed to create a vertical structure of control while ignoring the need for aggregating public interests (Böcskei 2013: $3)$. These priorities and weaknesses can be observed in the extensive legislative processes after FIDESZ's major electoral victories (2010, 2014, 2018), during which the two-third majorities passed a new Fundamental Law - which has been edited seven times since its coming into force on 1 January, $2012-$, reformed the election law, the municipal system, labor legislation, education, healthcare and the pension system (Sadecki 2014: 11). Though the reforms reflected real problems and offered effective solutions in numerous cases, extensive centralisation, a decrease in checks and balances and the degradation of the division of power served the priorities of the governing elite rather than public interest.

While the executive and legislative power did not make efforts for a widespread representation of interests, FIDESZ - as we have seen earlier - intentionally attempted to reflect and determine the political preferences of the Hungarian majority. This aim has highly influenced governing practices which have begun to use massive campaigning techniques, even in periods when otherwise no elections or referendums threatened the majoritarian rule of FIDESZ. Arthur J. Finkelstein, who was trained during the campaigns of Richard Nixon and Ronald Reagan, played a vital role in the definition of these extensive campaigns. The American policy adviser and his think-tank 
team, along with FIDESZ's tacticians, have developed a negative campaign strategy based on the existential fears of the middle classes and have created an overwhelming propaganda scheme that constantly tries to keep the government's rhetoric in focus (Kapronczay - Kertész 2018: 59). Political campaigns, which became regular features of Hungarian daily politics and life, were built on the exaggeration of the former governments' mistakes (e.g. "They have destroyed Hungary together!"), the overemphasised achievements of FIDESZ ("Hungary improves"), historical and national traditions ("Hungary is a strong and proud European country") and the creation of external adversaries ("Stop Brussels; Stop Soros; Say NO to illegal migration"). In these campaigns, a vital role was given to the constantly expanding governmental media empire which attempted to help FIDESZ's political strategies on both traditional and online platforms. These media platforms built up an alternative reality in which credibility was relative and the prevailing 'truth' was always determined by FIDESZ's opinion.

The extensive campaigning has attributed major importance to the personality and character of Viktor Orbán who has been an emblematic figure in the collapse of the Kádár regime and remained popular throughout all the 1990s and early 2000s. His personal successes are largely based on his excellent ability to adapt and transform, which turned the originally liberal FIDESZ into a right-wing, conservative 'catch-all' people's party (Lendvai 2016). The Prime Minister plays a central role in maintaining support of rightwing voters and besides active governance, he is also the most important actor of FIDESZ's political image. This image is designed and influenced by active political communication and campaigning which creates a Prime Minister figure who is pragmatic but value-orientated at the same time. According to the government's rhetoric, his pragmatic political decisions are driven by the values he represents. The protection of Hungarian traditions, culture and overall interest required the development of a strong government which now has the power to protect national sovereignty and wage conflicts when necessary. Thus, in this rhetoric, governance techniques based on a centralisation of power are not tools for reducing domestic liberties and rights but necessary features of defending national interests.

While the election results of previous years demonstrated the domestic effectiveness of these controversial governance practices, external opinions on Hungarian methods showed more diversity. While in the Western part of the EU, FIDESZ's power centralisation and conflicting foreign policy definitely undermined Orbán's government reputation, in CEE - and generally along the peripheries of the EU - the damage was not that obvious. Beyond geographic differences, the Orbán government's external reputation also highly depended 
on political opinions and beliefs. While generally the leftist, centrist and even moderate rightwing conservative voters seemed to reject Hungarian practices, the hardline conservatives, nationalists and rightwing radicals appear to have embraced them. The majority of the international press and dominant sections of the academic community were also less enthusiastic when commenting on Hungarian developments, although there is still a large minority who sympathise with Orbánian politics. Since effectiveness of (Hungarian) soft power's political factors is highly influenced by a government's international reputation, in the following sections, it is worth reviewing who embraces and who rejects political factors of Hungarian soft power.

To begin with the favoring opinions, it is apparent that the Orbán government, and the Prime Minister himself, have been particularly popular with CEE voters. Even though CEE members of the European People's Party supported the suspension of FIDESZ's membership in March 2019, the Hungarian government still retains relative popularity among the former socialist countries. According to a survey of the government-related Nézőpont Intézet, in 2018, an average of $63 \%$ of the respondents from surrounding countries favoured Hungary: $85 \%$ of Bulgarians, $74 \%$ of Slovakians, $73 \%$ of Czechs, $70 \%$ of Serbians, $60 \%$ of Poles, Slovenians, Croatians, as well as $39 \%$ of Romanians had a positive opinion about Hungary (Nézőpont 2018a). In relation to the Hungarian government's views on migration, the Slovaks, the Czechs and the Poles expressed positive feedback: an average of $58.3 \%$ of the sample from these countries supported the construction of a Hungarian border fence (Nézőpont 2018b).

Preferences of the CEE voters were in most cases respected by their political representatives which provided a sort of political shelter for the Hungarian government for years. This tendency was demonstrated by the votes related to the Sargentini report that was submitted to condemn the Hungarian government over the violation of basic European values. The voting distribution showed that the majority of Bulgarian, Czech, Polish, Slovakian and Slovenian representatives stood up to protect Orbán, while exactly half of the Croatian delegates also rejected the report. It is also notable that from the political groups of the EP, mainly the extreme rightist, anti-migration (Europe of Nations and Freedom, ENF) and conservative Eurosceptic (European Conservatives and Reformists, ECR) alliances defended Orbán and his party, while in FIDESZ's own family, the European People's Party, only 26.14\% opposed the passing of the report (Political Capital 2018). 
Figure 5: Voting distribution of the Sargentini report: Votes by Political Groups and Member States
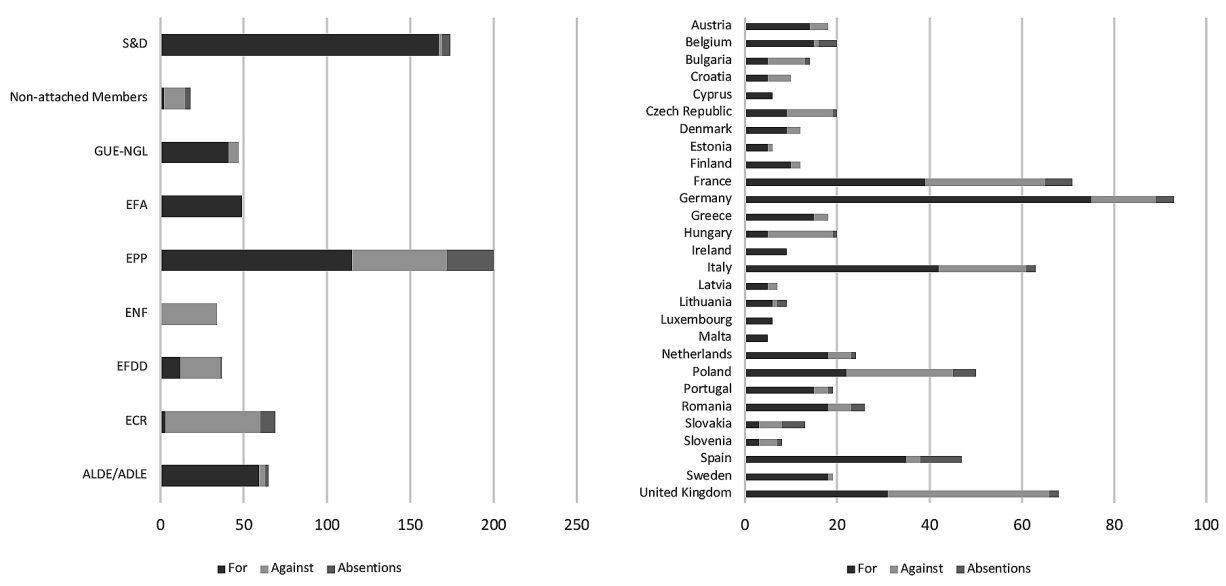

Votes of 693 MEPs. For: 448 (65\%); Against: 197 (28\%); Abstentions: 48 (7\%). Source: Vote Watch Europe: https://www.votewatch.eu.

Voting distribution of the EP's political groups on the Sargentini report does not only explain the suspension of FIDESZ from the European People's Party but also demonstrates which political communities favor the Hungarian government in Western Europe. Among those who recently labelled Hungary a positive example, we find mostly populist and rightwing-nationalist figures such as Matteo Salvini, Marine Le Pen, Nigel Farage or Geert Wilders. Beyond the borders of the EU, powerful illiberal allies such as Vladimir Putin and Recep Tayyip Erdoğan also praised the friendliness of Hungarian foreign policy, while Benjamin Netanyahu recently gave positive feedback on the decreasing tendency of anti-Semitism in Hungary (Sternhell 2019). Besides the top politicians, academic experts and political advisers also voiced their sympathy towards Orbán's methods. Donald Trump's former chief adviser, Steve Bannon, named the Hungarian Prime Minister a hero, while another former presidential adviser, Jeffrey D. Gordon, claimed him to be one of the best leaders in the world (Micklethwait - Morales - Alfaro 2018; Keszthelyi 2016). Few from the academic arena also embraced the Prime Minister: American historian Daniel Pipes, for instance, called Viktor Orbán the most important European (Pipes 2018).

While CEE countries have an apparent but faltering tendency to support Orbánian practices, public opinions, politicians, academics and journalists in Western Europe seem to follow a more critical attitude. Although positive reactions towards the Hungarian government also have some reserves in those Western European countries where populist movements seem to be attractive, nationalist, anti-migration, Eurosceptic and right-wing radical movements do 
not reflect the opinion of the majority. In Western Europe, moderate actors of the political elite, the majority of the academic community and a significant part of the press reject the rhetoric of the Hungarian government. This tendency is clearly shown by various survey results. Just to mention two, for instance: while Czech respondents selected Viktor Orbán as the third most credible politician in 2019, according to Nézőpont Intézet's survey conducted in the summer of 2018, 55\% of the Germans judged Hungary unfavourably (CVVM 2019; Nézőpont 2018c).

German public opinion doesn't just reflect the view of many other moderate voters but also mirrors the responses of the Western European political elite. At this point, voting distribution of the Sargentini report, again, an important point of reference in which not just the European left and the liberals condemned the Hungarian government, but former allies such as Manfred Weber, Sebastian Kurz, Joseph Daul and Daniel Caspary have also distanced themselves from FIDESZ's side (Political Capital 2018).

Beyond the public and political elite, the Western press also has a tendency to criticise Hungarian political developments. In 2016, Nézőpont Intézet, after examining 13,261 articles of 18 countries' 115 printed and online media products, came to the conclusion that about $29 \%$ of the articles judged Hungary negatively, $68 \%$ neutrally and only $3 \%$ of the articles considered Hungarian developments to be positive. Germany has proven to be the most critical country towards Hungary that year, where $60 \%$ of the articles condemned the country, followed by Israel (53\%), Italy (51\%) and France (50\%) (Nézőpont 2016).

Lastly, it is important to point out that, beyond the aforementioned layers of Western European political societies, the Hungarian government also failed to convince analysts and observers of various international and non-governmental organisations. As a result, from Human Rights Watch through Freedom House to Amnesty International, many IGOs and NGOs have criticised recent events in Hungary and pointed out a tendency of decreasing democratic principles (HRW 2019: 231-233; Abramowitz 2018:16).

All in all, the Hungarian government's international reputation is rather controversial, which highly influences the effectiveness of its soft power. To quote Nye once again, although support of the public masses, credible domestic and external interactions and a positive self-image could increase the effects of soft power, the lack of these elements may also undermine it (Nye 2004: 14). Political projections of Hungarian soft power profits and, at the same time, suffers from these tendencies. Regarding support from public masses, the Hungarian Prime Minister profits significantly from widescale domestic and relative central European popularity: in contemporary European politics, Viktor Orbán is the only leader - besides the resigning Angela Merkel - who has managed to remain in power since 2010. This continuity in domestic policy has greatly increased Viktor Orbán's ability to shape international agendas and has made 
him a decisive factor in several significant European issues such as migration politics. This attractiveness originated from domestic stability and regional popularity, however, is greatly decreased by the fact that Orbán is greatly criticised in Western Europe where he is being more and more challenged, both in the political and moral sense.

Western criticism is highly influenced by another crucial factor of soft power's effectiveness: The Hungarian government fails to demonstrate its credibility both at home and abroad. Although it spends billions of forints on political campaigning, the Orbán government only seeks to build communication frameworks of its alternative answers and pay less effort to the validity and credibility of its messages. While at home, mainly widescale corruption charges decrease the credibility of FIDESZ, in Europe, illiberal governance methods, anti-EU rhetoric, Soros propaganda and Russian-friendly foreign policy also hinder Hungarian leadership's international image. These actions push the Hungarian government away from the moderate conservative and right-wing majority and embed FIDESZ in the European far-right. The radicalisation of FIDESZ's political image, however, is often increased by intentional political manoeuvres: moderate European parties within the European Parliament are obviously attempting to decrease FIDESZ's limited positive reputation by labelling the party as far-right, fascist or anti-Semitic.

\section{Foreign policy}

In the last section of the study, I will attempt to identify those segments of the broadly interpreted Hungarian foreign policy that presumably increased and constrained the effectiveness of soft power. My starting point is once again Nye's interpretation, who stated that soft power could only become an effective external tool if foreign policy creates international legitimacy and moral authority (Nye 2004: 11). According to this view, the international image of a government is considered positive when foreign policy is effective and whose success also increases the given leadership's domestic and external political capital. However, in the case of ineffectiveness, the international image might become repulsive, which can critically decrease international and domestic policy opportunities.

The Hungarian leadership has clearly realised these characteristics and, alongside its conflicting rhetoric, has launched several official and non-official strategies to internationally popularise Hungarian views and increase its damaged reputation. One of the most effective fields of these strategies was external communication which was supported by both government-controlled efforts and indirect effects of controversial international fame. The range of direct communication strategies directed to influence foreigners was extremely wide, scaling from the press conferences and European Parliament statements 
through the websites of the governmental institutions to official media and online releases. The centralised approach to communication is excellently phrased by the National Communication Office, which states that, "the aim of the Government is that all financial organisations (...) or institutions under the control or supervision of the Government (...) perform activities that are in harmony with the Government's communication goals" (Nemzeti Kommunikációs Hivatal 2019). In the meantime, the latter approach was not only true for government organs and institutions but also determined the communication duties of government-related politicians and state employees. This tendency was also reflected in international communication, traceable in press statements (e.g. interviews with Hungarian FM Péter Szijjártó on CNN, BBC, Al Jazeera, CBN etc.), in speeches at international organisations and in FIDESZ's speeches in the European Parliament (see: EPTV).

The other vital domain of external political communication was state- or government-controlled media. Among these, we must highlight the Hungarian News Agency's (MTI) English news service, which reports as both Daily Bulletin and Newsletter (Hungary Matters), as well as the Hungarian Television's daily news program which broadcasts in English, German, Russian and Chinese. The most significant online interfaces designed for international audiences are the English and Romanian pages of hirado.hu, as well as the English and German sites of Hungary Today/Ungarn Heute, both of which having a large number of followers on popular social media sites as well. ${ }^{2}$ Beyond ordinary foreigners, the Hungarian government also pays special attention to reach the Hungarian diaspora abroad, especially the minorities living in the Carpathian Basin. The platforms of such diaspora-directed broadcasts are usually Duna TV and Hungarian National Radio (Magyar Rádió). The latter one - mostly for cultural rather than political reasons - also transmits Polish, Slovakian, Ukrainian, Greek, Bulgarian, Romanian, Croatian and German programs for the respective minorities living in Hungary. Last but not least, it is important to highlight that communication strategies are also benefiting from the regional expansion of certain Hungarian enterprises which purchased media outlets throughout Central Europe and the Balkans. These platforms often provide further opportunities for the propagation of the Hungarian government's messages.

According to the Soft Power 30 survey - which was quoted at the beginning of the study - in previous years, Hungary has been advancing rapidly in the field of digital developments. This advance was undoubtedly true for the online political activity of the government, which has become one of the most important segments of communication besides those listed above. The Hungarian government sensibly attached elevated importance to online platforms which are now part

2 Facebook followers of Hungary Today: 66853; Facebook followers of Ungarn Heute: 16553. Data collected on 28 January 2019. 
of bureaucracy, information campaigns and political mobilisation. The official website of the government offers constantly updated content in English and most of the governing politicians, state institutions or press products have official profiles on social media. The most popular among these are Viktor Orbán's profiles who, besides being present on Twitter and Instagram, maintains up-to-date Facebook profiles in both Hungarian and English.

Hungarian leadership's international communication also includes advertisements in public spaces, online ads and uses marketing tools such as promotions, event marketing, presence at fares and sponsorship. Hungary spends billions of forints on such activities as it believes that, "it is essential for international public opinion - besides domestic public opinion - to learn about the views and opinions of Hungary" (Nemzeti Kommunikációs Hivatal 2019). It is an important component of this strategy that, besides the directly controlled publications, indirect media publicity can also help to inform international public opinion. Though in this case the Hungarian government's positive judgement is not guaranteed at all, the political messages represented by it can still be indirectly transmitted to foreign audiences. Figure 6 points out the importance of indirect media publicity by comparing publications about Viktor Orbán and Miloš Zeman based on online databases of major international press organisations. The most informative part of the figure is not the fact that Orbán received greater publicity by representing a more conflicting foreign and domestic policy; it is more like the fact that the indirect press releases provided wider publicity for free than direct communication which cost billions.

\section{Figure 6: Number of press releases about Viktor Orbán and Miloš Zeman}

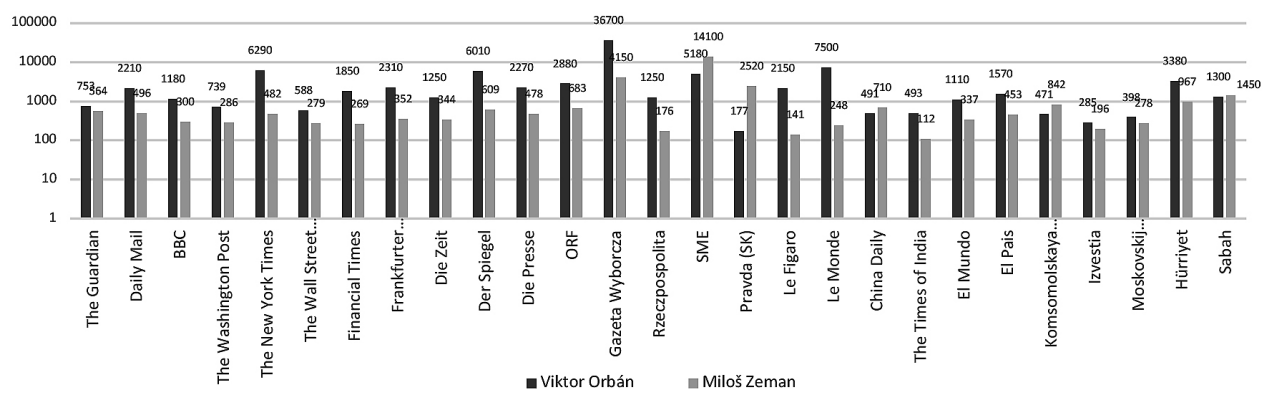

Source: google.com, last updated on 29/01/2019

Beyond communication, the Hungarian government's international image is influenced by other means of soft power. Among the official platforms, the network of diplomatic missions and state leader visits are worth having a look at. In 2015, Hungary had the 48th largest number of embassy networks out of 196 
countries, which were supplemented by a series of consulates and permanent representations delegated to international organisations (Kacziba 2018). Beyond these permanent delegations, visits of state officials also served important foreign political purposes. In relation to official visits, we can attach particular importance to Viktor Orbán once again, as he spent 67 days in total abroad and visited 33 foreign destinations in 2017 (Lőrincz 2018). The country has also practised active cultural and sport diplomacy. Currently, the country finances the operations of 25 cultural delegations abroad whose posts popularise Hungarian culture in cities such as New York, London, Istanbul, New Delhi and Beijing, among others (Balassi Intézet 2018). The Orbán governments have also attributed special attention to the international attraction of sport: while in 2010, only 32 international sports events were hosted in Hungary, this number increased to 113 by 2017 (Jandó 2019).

In recent years, Hungary has also actively attempted to compensate for its anti-migration image by aiding persecuted Christians around the World. This policy developed its institutional frameworks in 2016 when the office of 'Deputy Secretary of State for Assisting Persecuted Christians' was founded. The office - under the Hungary Helps program - had already supported Christians with a total of 4.5 billion forints by October 2018, mostly in the crisis zones of the Middle East and Africa. The program supported the (re)construction of religious and educational infrastructure in Iraq, Lebanon, Syria, Jordan and Nigeria and it also provided scholarships and education in Hungary for 187 students originating from various crisis zones (Miniszterelnökség 2018). Another popular and much more extensive educational program of the Hungarian government was the Stipendium Hungaricum scholarship, which financed the higher education of 5,148 foreign students in 2017. The program reflected the geographical orientation of Global Opening foreign policy: during the sample year of 2017, most of the students came from Jordan (476), China (387), Azerbaijan (333) and other developing countries such as Mongolia, Laos, Kazakhstan or Tunisia (Tempus Közalapítvány 2018).

Another highlighted sphere of the government's external aiding activity has focused on Hungarian minorities and diaspora in the Carpathian Basin. This target group is unquestionably the most successful area of Hungarian soft power. Hungary's success in this group is based on deep historical and political roots, as well as on extensive economic support coming from Budapest through various programs. These state-based, bilateral or EU-funded programs have aided Hungarian minorities and their organisations in the fields of economy and infrastructure improvement, enterprise and business development, as well as education and culture, among other examples. The Hungarian government has also supported the diaspora by providing citizenship through a simplified naturalization procedure. As of May 2017, the new citizenship law of January 2011 granted about 835.000 new citizenship to ethnic Hungarians residing abroad, 
while another 115.000 new citizens acquired nationality through standard application procedures (Kovács 2017). These new citizens have begun to play an essential role in domestic politics as well. Since 2014, the gradually expanding group of new citizens have received the right to vote in parliamentary elections, and especially impacted the proportions of party-list votes.

Finally, it is important to point out that Hungarian foreign policy intentionally attempts to exploit the weight of its international embeddedness. EU and NATO membership of the country is a significant factor of Hungarian soft power and the government intentionally tries to exploit this in its international activities. Outside the EU and NATO, Hungary often acts as an ambassador for these organisations and it tries to exploit the political and economic advantages of its memberships and veto power.

Although positive practices such as the aiding of persecuted Christians or the scholarship programs for foreign students definitely have some positive impacts, good precedents and extensive propaganda campaigns could not annul the negative consequences of conflicting foreign policy. In recent years, beyond the limited efforts to improve the country's international legitimacy and moral authority, the reputation of the Hungarian government was also judged through the overall characteristics of its foreign activities from which the 'domestication' of foreign policy and the Global Opening doctrine have seriously undermined Orbán's government's external image. From these two, the 'domestication' of foreign policy meant that the influence of domestic politics had a much greater impact on Hungarian foreign policy than necessary: by 2014, the frameworks of Hungarian foreign policy were not defined by its international embeddedness and alliance structures, rather, by the needs of justifying internal political developments (Deák 2013: 163). The 'domestication' of foreign policy was a direct result of FIDESZ's efforts of centralisation which did not only limit the decision-making autonomy of the Ministry of Foreign Affairs but also entrusted diplomatic personnel with the task of protecting and justifying domestic developments abroad. Of course, this would not count as an irregular request, but it placed Hungarian diplomacy into disadvantageous situations in which the constant explanations and excuses discredited highly respected diplomats and often undermined their decade-long work. Consequently, the new tasks also required new diplomatic staff: after the elections in 2014, an extensive dismissal process took place in the Ministry of Foreign Affairs which replaced Foreign Minister János Martonyi and his wider circle of experienced and proficient diplomatic staff. By 2015, the almost entirely new diplomatic personnel led by Foreign Minister Péter Szijjártó implemented the new directions without hesitation and exported domestic political views on central issues such as migration, the European Union and economic freedom fighting.

Beyond the large impact of domestic politics on foreign policy, the doctrine of Global Opening has also undermined Hungary's external reputation. The 
doctrine, which has diversified Hungary's previously EU-, USA- and NATO-based foreign policy, has evolved from Viktor Orbán's regime founding ideas that, along with domestic changes, aimed to reform external relations and reduce Hungary's unilateral dependence on the West. The original framework of this new foreign policy direction was determined by the doctrine of Global Opening which first redirected Hungary's attention towards the global East (2010) and then to the global South (2015). The often-criticised new approach, according to the official explanation, was meant to respond to new global trends and intended to channel the Hungarian economy into seemingly skyrocketing developing markets. The new strategy made efforts to establish cooperation with globally (Russia, China) and regionally (Turkey) significant countries and also resulted in a more active and sometimes more confrontational foreign policy towards neighbouring countries (Tarrósy - Vörös 2014: 145-151, 155-157).

Though the original economy-oriented idea of Global Opening did not aim to divert the country from its traditional Euro-Atlantic direction, domestic illiberal measures, friendly relations with Russia and anti-EU rhetoric automatically generated antagonistic feelings among Hungary's Western allies. Increasing Western criticism and the Orbán government's harsh responses to it further deepened disputes between Hungary and its NATO and EU allies while raising the importance of Moscow, Beijing and Ankara who were all anxious to exploit the effects of these new oppositions. This parallel process has created an interesting constellation in which Hungarian foreign policy undermined its own legitimacy among its allies; meanwhile, it simultaneously increased its reputation among those who were obvious international competitors of these Western allies.

This controversial international position provided opportunities but also served as a great limitation. In terms of opportunities, Hungary's "rogue behaviour" often increased its agenda-setting capacity, especially within the EU where certain member states and officials hoped to appease and control Budapest by offering larger involvement. The FIDESZ could also exploit its conflicting image in communication terms. Its messages directed to the foreign public began to propagate that Hungary approaches the most critical contemporary challenges differently to others in the mainstream: Hungary considers protection of the states' independence and sovereignty as a vital issue, it rejects the social tensions generated by multiculturalism and migration and views the unilateral dependence on the West as a political and economic mistake. The EU critical approach has personally increased the fame of Viktor Orbán who even began to cherish European dreams after his election victory in 2018. As the Prime Minister put it: "We thought 30 years ago that Europe is our future; today we think that we are Europe's future" (Bíró 2019). This future - according to Orbán — will be determined by the committed Christian, anti-communist, nationalist generation of the 1990s who will replace the liberal "European elite of '68" (Ibid). According 
to FIDESZ's rhetoric, in this process, Hungary has to act as a role model and should export its domestic practices to the European sphere.

Besides the advantages, Hungarian foreign policy - along with the impacts of its soft power - suffers from serious limitations as well. Even though the country has developed strategies to compensate for its controversial decisions, its international legitimacy and moral authority still suffer from policies that are incompatible with values and interests of Western European countries. It is important to point out, however, that these Western European countries are not just random members of the international community, they are allies of Hungary; states which not only share cultural, historical and civilisation similarities with the Hungarians but which have also provided economic and financial support for them. Members of the EPP have sent a clear message to the Hungarian government regarding what they expect in return for this support: FIDESZ should stop campaigning against the EU and must begin to act as an actual ally. Recent consultations between Viktor Orbán and Matteo Salvini indicate that Hungary may again choose a different, more conflicting path of foreign policy. These conflicting policies will definitely bring some short-term advantages, however, in the long run, they seemingly block the development of an externally positive self-image which would be much needed for the efficiency of soft power. Thus, it seems that foreign policy is the weakest political metric of Hungarian soft power: while some programs definitely increased Hungary's external reputation, the overall characters of a conflicting foreign policy framework oppose the basic theoretical assumptions and practical examples of effective soft power and therefore undermine the international image that other factors may have improved upon.

\section{Conclusion}

This study has attempted to examine which political factors could have been exploited by Hungarian soft power and how politics affected the international reputation of contemporary Hungary. The paper has used three widely interpreted political spheres during the detection of the most effective segments of soft power tools: political values, the efficiency of domestic governance and the attraction of foreign policy actions. In the case of political values, I reviewed the Hungarian government's ideological explanations and analysed their possible international attraction. In the context of governance, I outlined governing strategies and examined the international reputation of Hungarian domestic methods and nationally achieved results. In relation to foreign policy, I identified tools that sought to increase the efficiency of Hungary's soft power, while also pointing out the limitations of a conflicting foreign policy framework.

It became apparent during the analysis that politics and political strategies have truly become one of the most important pillars of Hungarian soft power 
and it was also outlined how the country has developed a strategy that intends to increase its external popularity and agenda-setting capacity based on political efficiency. In this strategy, domestically tested political values and governance techniques were projected towards an international audience and were able to gain ground among those who supported populist policies and were critical towards the mainstream political landscape. The success of Hungarian soft power, however, proved to be relative and was seriously constrained by the opinions that condemned Orbán's policies and decisions. Analyses of political values, governance techniques and foreign policy practices all indicated the presence of this duality: success of Hungarian soft power was significantly limited by the conflicting and controversial policies that undermined the legitimacy and moral authority of projected ideologies.

This duality perfectly demonstrates the controversy of Hungarian soft power's effectiveness. On the one hand, it is obviously observable that Hungarian soft power was effective on those who were open and attracted to Orbán's messages and political views. On the other, the political background and orientation of this audience constantly diverts the popularity of the Hungarian government towards the extreme right which is clearly flattering for the populist Orbán but is not advantageous in the long run. Weaknesses of Hungarian soft power are related to this close extremist connection: in the eyes of the Western political elite and the moderate majority, the Hungarian government's reputation is critically negative which hinders the effectiveness of soft power in those groups which are the most important for Hungary from the aspects of politics, economy and culture. These characteristics influence not only the effectiveness of Hungarian soft power but also undermine the country's credibility in the international arena.

\section{References}

Abramowitz, Michael J. (2018): Democracy in Crisis - Freedom in The World 2018. Freedom House, available at https://freedomhouse.org/sites/default/files/FH_FITW_Report_2018_Final_SinglePag e.pdf (06 May 2019).

Bihari, Mihály (2013): POLITOLÓGIA - A politika és a modern állam, Pártok és ideológiák. Budapest: Nemzedékek Tudása Tankönyvkiadó Zrt.

Bíró, Marianna (2019): 'Tényleg Orbán jelentené Európa jövőjét?', 168 óra - Közéleti Hetilap, available at https://168ora.hu/itthon/tenyleg-orban-jelentene-europa-jovojet-161904 (07 May 2019).

Böcskei, Balázs (2013): A repolitizált politika és a kormányzás - Bevezetés a második Orbán-kormány jog- és politikafelfogásába. Jogelméleti Szemle 2013(4): 1-12.

Bretter, Zoltán (2014): Halfway or no way. Politeja - Pismo Wydziału Studiów Miedzynarodowych i Politycznych Uniwersytetu Jagiellońskiego 2(28): 5-30. 
CVVM (2019): Confidence in some Representatives in International Context - December 2018. Public Opinion Research Centre, Institute of Sociology, Academy of Sciences of the Czech Republic, available at https://cvvm.soc.cas.cz/media/com_form2content/documents/c6/ a4826/f77/pm190211.pdf (06 May 2019).

Deák, András (2013): Hungarian Dances - The Origins and the Future of Viktor Orbán's Revolution. Lithuanian Annual Strategic Review 11(1): 145-168.

Ethridge, Marcus E. - Handelman, Howard (2010): Politics in a Changing World. Boston: Wadsworth, Cengage Learning.

G. Fodor, Gábor (2008): Jó és rossz kormányzás Magyarországon, avagy a demokratikus minőség mérésének problémája. Politikatudományi Szemle 17(1): 131-144.

G. Fodor, Gábor - Fűrész, Gábor - Giró-Szász, András (2010): Az ideológiák vége. A Nemzeti Együttműködés Rendszere. Századvég Alapítvány, Budapest: available at http://www.szazadveg.hu/files/kutatas/5.pdf (13 November 2018).

G. Fodor, Gábor - Stumpf, István (2007): A „jó kormányzás” két értelme. Avagy a demokratikus kormányzás programja és feltételei. Nemzeti Érdek 2007(3): 76-95.

Geuss, Raymond (2009): What is Political Judgement? In Bourke, Richard - Geuss, Raymond. Political Judgement - Essays for John Dunn. Cambridge, Cambridge University Press. 29-46.

Glied, Viktor - Keserű, Dávid (2016): Migrációs kihívások az Európai Unióban. In Tarrósy, István Glied, Viktor - Vörös, Zoltán, eds. Migráció a 21. században. Pécs, Publikon Publishers. 259-293.

Glied, Viktor - Pap, Norbert (2016): The 'Christian Fortress of Hungary' - The Anatomy of the Migration Crisis in Hungary. In Yearbook of Polish European Studies, Vol. 19. Warsaw, Centre for Europe, University of Warsaw. 133-149.

Habermas, Jürgen (1975): Legitimation Crisis. Boston: Beacon Press.

Heath, Ryan (2016): 'Power matrix: Ranking Europe's leaders and ambassadors: Here's who's really in charge in Brussels', POLITICO, available at https://www.politico.eu/interactive/power-matrix-charting-the-eu-players-by-country-european-council-national-capitals-leaders-ambassadors/ (06 May 2019).

HRW (2019): World Report 2019 - Events of 2018. Human Rights Watch, available at https:// www.hrw.org/sites/default/files/world_report_download/hrw_world_report_2019.pdf (06 May 2019).

Huntington, Samuel P. - Crozier, Michel - Watanuki, Joji (1975): The Crisis of Democracy: Report on the Governability of Democracies to the Trilateral Commission. New York: New York University Press.

Illés, Gábor István - Körösényi, András - Metz, Rudolf Tamás (2017): Orbán Viktor mint rekonstruktív vezető. In Boda, Zsolt - Szabó, Andrea. Trendek a magyar politikában. Budapest, Napvilág Kiadó. 110-142.

Jandó, Zoltán (2019): 'Káoszba süllyedt a kormány terve, hogy jobban szervezzék a nagy sportrendezvényeket', G-7.hu Nonprofit Zrt., available at https://g7.hu/kozelet/20190218/kaoszba-sullyedt-a-kormany-terve-hogy-jobban-szervezzek-a-nagy-sportrendezvenyeket/ (07 May 2019). 
Kacziba, Péter (2018): A nemzetközi kapcsolatok hálozattudományi megközelítései. Politikatudományi Szemle 2018(4): 133-156.

Kapronczay, Stefánia - Kertész, Anna (2018): The Crackdown on NGOs as an Opportunity to Reinforce Human Rights Values: A Hungarian Case Study. In Rodríguez-Garavito, César - Gomez, Krizna. Rising to the Populist Challenge: A New Playbook for Human Rights Actors. Dejusticia. 57-68. Available at https://www.dejusticia.org/wp-content/uploads/2018/04/Rising-to-the-populist-challenge_1.pdf (06 May 2019).

Keszthelyi, Christian (2016): 'Trump adviser: Orbán aims to make Hungary great again', Budapest Business Journal, available at https://bbj.hu/politics/trump-adviser-orban-aims-to-makehungary-great-again-_125690 (06 May 2019).

Kovács, Zoltán (2017): 'The big deal about Hungary's almost 1 million new citizens', About Hungary, available at http://abouthungary.hu/blog/the-big-deal-about-hungarys-almost-1million-new-citizens/ (06 May 2019).

Lendvai, Paul (2016): Orbán - Europe's New Strongman. New York: Oxford University Press.

Lewis, Paul - Clarke, Seán - Barr, Caelainn - Holder, Josh - Kommenda, Niko (2018): 'Revealed: one in four Europeans vote populist - Exclusive research shows how populists tripled their vote over the past two decades', Guardian, available at https://www.theguardian.com/world/ ng-interactive/2018/nov/20/revealed-one in-four-europeans-vote-populist (06 May 2019).

Lőrincz, Tamás (2018): 'Több százmillióba kerültek Orbán külföldi útjai', Népszava, available at https://nepszava.hu/3002194_tobb-szazmillioba-kerultek-orban-kulfoldi-utjai (07 May 2019).

McClory, Jonathan (2010): The New Persuaders: An international ranking of soft power. The Institute for Government, London: available at https://www.instituteforgovernment.org.uk/ sites/default/files/publications/The\%20ne w\%20persuaders_0.pdf (06 May 2019).

McClory, Jonathan (2018): The Soft Power 30: A Global Ranking of Soft Power 2018, Portland Communications \& USC Center on Public Diplomacy: available at https://softpower30.com/ wp-content/uploads/2018/07/The-Soft-Power-30-Report-2018.pdf (06 May 2019).

Micklethwait, John - Morales, Alex - Alfaro, Tiago Ramos (2018): Bannon Lauds Orban as ‘Heroic,' Says Euro Should Be Abandoned. Bloomberg, available at https://www.bloomberg.com/ news/articles/2018-10-10/bannon-lauds-orban-as-heroic-says-euro-should-be-abandoned (06 May 2019).

NER (2010): A Nemzeti Együttműködés Programja, Magyar Országgyűlés, available at https:// www.parlament.hu/irom39/00047/00047.pdf (06 May 2019).

Nézőpont Intézet (2016): Magyarország a világsajtóban 2016. Nézőpont Csoport Zrt.: available at https://nezopontintezet.hu/wp-content/uploads/2016/02/Magyarorszag-avilagsajtoban-2015.pdf (16 January 2019).

Nézőpont Intézet (2018a): A Közép-Európaiak kétharmada szimpatizál Magyarországgal. Nézőpont Csoport Zrt.: available at https://nezopontintezet.hu/2018/02/28/a-kozepeuropaiak-ketharmada-szimpatizal-magyarorszaggal/ (06 May 2019).

Nézőpont Intézet (2018b): V4 Countries Stand United Against Immigration. Nézőpont Csoport Zrt.: available at https://Nezopontintezet.Hu/En/2018/12/13/V4-Countries-Stand-United-Against-Immigration/ (06 May 2019). 
Nézőpont Intézet (2018c): Viszonzatlan a magyarok németbarátsága. Nézőpont Csoport Zrt.: available at https://nezopontintezet.hu/analysis/viszonzatlan-magyarok-nemetbaratsaga/ (15 January 2019).

Nye, Joseph S. (1990): Soft Power. Foreign Policy 80, Twentieth Anniversary Edition: 153-171.

Nye, Joseph S. (2004): Soft Power: The Means to Success in World Politics. New York: Public Affairs.

Nye, Joseph S. (2008): Public Diplomacy and Soft Power. Annals of the American Academy of Political and Social Science 616, Public Diplomacy in a Changing World (March 2008): 94-109.

Olivié, Iliana - Gracia, Manuel (2018): Elcano Global Presence Report, 2018, Real Instituto Elcano, Madrid: available at www.realinstitutoelcano.org (06 May 2019).

Pew Research (2017): Democracy, nationalism and pluralism. Religious Belief and National Belonging in Central and Eastern Europe, Pew Research: available at https://www.pewforum. org/2017/05/10/democracy-nationalism-and-pluralism/ (06 May 2019).

Pipes, Daniel (2018): 'A look at the Continent's leaders', The Washington Times available at https://www.washingtontimes.com/news/2018/aug/1/who-are-europes-most-important-politicians/ (06 May 2019).

Political Capital (2018): The approval of the Sargentini report: the beginning of the end for Orbán in the European People's Party? Political Capital Policy Research and Consulting Institute: available at https://www.politicalcapital.hu/pcadmin/source/documents/pc_flash_report_sargentini_20180912.pdf (12 April 2019).

Rajcsányi, Gellért (2018): Viktor Orbán's Hungary: Orbanist Politics and Philosophy from a Historical Perspective. In Echle, Christian - Kliem, Frederick - Sarmah, Megha. Political Change, Panorama: Insights into Asian and European Affairs. Singapore, Konrad-Adenauer-Stiftung. 123-134.

Sadecki, Andrzej (2014): In a state of necessity - How has Orban changed Hungary. Center for Eastern Studies, Warsaw, available at https://www.osw.waw.pl/sites/default/files/pw_41_in-a-state-of-necessity_net.pdf (04 May 2019).

Sternhell, Zeev (2019): Why Benjamin Netanyahu Loves the European Far-Right. Foreign Policy online, available at https://foreignpolicy.com/2019/02/24/why-benjamin-netanyahu-loves-the-european-far-right-orban-kaczynski-pis-fidesz-visegrad-likud-antisemitism-hungary-poland-illiberalism (02 May 2019).

Stumpf, István (2009): Az állam újrafelfedezése és a Neoweberiánus állam. In Virág, György. OKRI Szemle. Budapest, Országos Kriminológiai Intézet. pp. 110-124.

Tarrósy, István - Vörös, Zoltán (2014): Hungary's Global Opening to an Interpolar World. Politeja (28): 139-162.

Tóth, István György (2009): Bizalomhiány, normazavarok, igazságtalanságérzet és paternalizmus a magyar társadalom értékszerkezetében - A gazdasági felemelkedés társadalmi-kulturális feltételei című kutatás zárójelentése. Budapest: Tárki Társadalomkutatási Intézet

Vörös, Zoltán (2018): The Nikola Gruevski-case - Two potential scenarios on why Hungary helped the former Macedonian PM. Der Donauraum 58 (3-4): 169-184. 
Wike, Richard - Fetterolf, Janell (2018): Liberal Democracy's Crisis of Confidence. Journal of Democracy 29(4): 136-150.

\section{Official websites:}

Balassi Intézet: available at http://www.balassiintezet.hu (07 May 2019).

European Comission (2013): Standard Eurobarometer 80; available at http://ec.europa.eu/ commfrontoffice/publicopinion/index.cfm/Survey/index\#p=1\& instruments=STANDARD (05 May 2019).

European Comission (2018): Standard Eurobarometer 90; available at http://ec.europa.eu/ commfrontoffice/publicopinion/index.cfm/Survey/index\#p=1\& instruments=STANDARD (05 May 2019).

kormány.hu (2014): Prime Minister Viktor Orbán's Speech at the 25th Bálványos Summer Free University and Student Camp, retrived from the official website of the Hungarian Government: available at https://www.kormany.hu/en/the-prime-minister/the-prime-minister-s-speeches/ prime-minister-viktor-orban-s-speech-at-the-25th-balvanyos-summer-free-university-and-student-camp (06 May 2019).

Miniszterelnökség [Cabinet Office of the Prime Minister]: Az üldözött keresztények megsegítéséért és a Hungary Helps Program megvalósításáért felelős államtitkárság, available at https://www.kormany.hu/hu/miniszterelnokseg/az-uldozott-keresztenyek-megsegiteseert-es-a-hungary-helps-program-megvalositasaert-felelos-allamtitkar (07 May 2019).

Nemzeti Kommunikációs Hivatal [National Communication Office]: available at http://nkoh. kormany.hu/ (05 May 2019).

Tempus Közalapítvány (2018): Stipendium Hungaricum programhoz kapcsolódó statisztikák, available at https://tka.hu/palyazatok/7619/statisztikak (07 May 2019).

Vote Watch Europe: available at https://www.votewatch.eu (05 May 2019).

Péter Kacziba is an assistant professor at the Department of Political Science and International Studies, University of Pécs, Hungary. He studied history and holds a, Ph.D. in political science. He is a lecturer of several university courses including Theories of International Relations, Theories and Practices of International Conflict Resolution and World History in the 20th century. His research interests focus on conflicts and conflict resolutions in the Eastern Mediterranean region, as well as on the network paradigm of International Relations.Email: kacziba.peter@pte.hu 